Portland State University

PDXScholar

\title{
Enhancing Bicycle and Pedestrian Education through Curriculum and Faculty Development
}

Lynn Weigand

Portland State University

Follow this and additional works at: https://pdxscholar.library.pdx.edu/trec_reports

Part of the Transportation Commons, and the Urban Studies Commons Let us know how access to this document benefits you.

\section{Recommended Citation}

Weigand, Lynn. Enhancing Bicycle and Pedestrian Education through Curriculum and Faculty Development. OTREC-ED-12-01. Portland, OR: Transportation Research and Education Center (TREC), 2013. https://doi.org/10.15760/trec.1

This Report is brought to you for free and open access. It has been accepted for inclusion in TREC Final Reports by an authorized administrator of PDXScholar. Please contact us if we can make this document more accessible: pdxscholar@pdx.edu. 


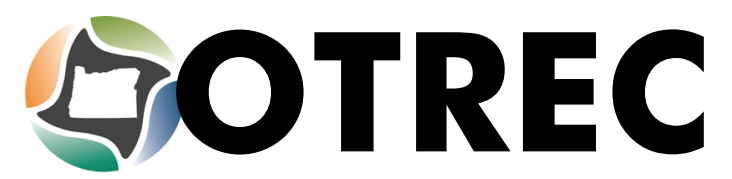

ORECON
TRANSPORTATION

RESEARCH AND

FINAL REPORT

Enhancing Bicycle and
Pedestrian Education

Through Curriculum and

Faculty Development

OTREC-ED-12-01

January 2013 



\title{
ENHANCING BICYCLE AND PEDESTRIAN EDUCATION THROUGH CURRICULUM AND FACULTY DEVELOPMENT
}

\section{Final Report}

\section{OTREC-ED-12-01}

\author{
by \\ Lynn Weigand, Ph.D. \\ Portland State University
}

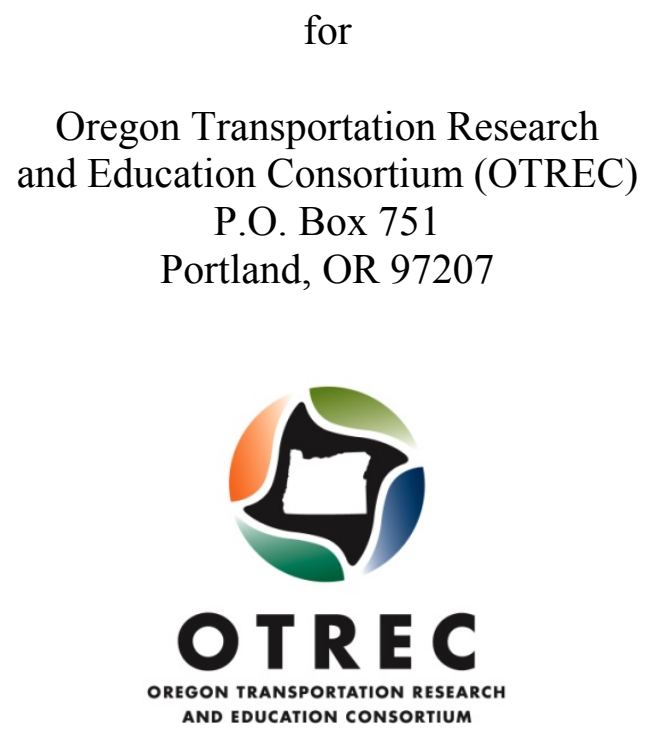

January 2013 








\section{ACKNOWLEDGEMENTS}

I would like to thank Rose Jackson and Sarah Beasley at the Millar Library for their assistance in acquiring new library resources as part of this project, and Caroline Chapman for her work on this project as graduate research assistant.

\section{DISCLAIMER}

The contents of this report reflect the views of the authors, who are solely responsible for the facts and the accuracy of the material and information presented herein. This document is disseminated under the sponsorship of the U.S. Department of Transportation University Transportation Centers Program and OTREC in the interest of information exchange. The U.S. Government and OTREC assume no liability for the contents or use thereof. The contents do not necessarily reflect the official views of the U.S. Government and OTREC. This report does not constitute a standard, specification, or regulation. 


\section{TABLE OF CONTENTS}

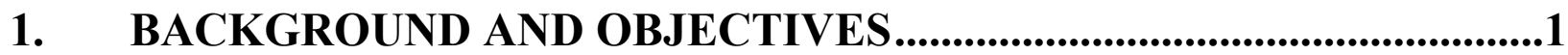

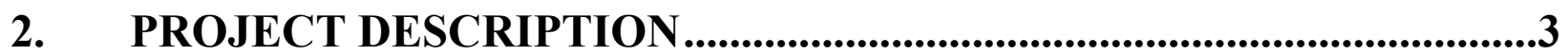

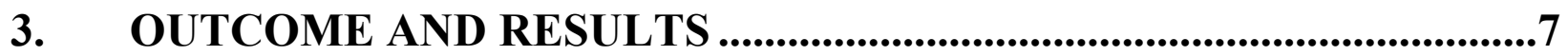

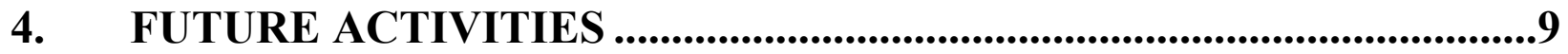

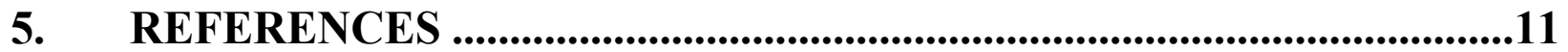

APPENDIX A： LIBRARY RESOURCES ACQUIRED.....................................13

\section{LIST OF TABLES}

TABLE 1: CURRICULUM SCAN PARTICIPANTS ......................... 3 


\section{EXECUTIVE SUMMARY}

This project was intended to provide relevant curriculum modules on bicycle and pedestrian transportation that can be used by planning and engineering faculty to integrate these topics into their course offerings. We developed a module-based curriculum for bicycle and pedestrian planning and design that is current, relevant to practice, and adaptable for use in a variety of course offerings in engineering and planning departments.

We conducted a scan of university-based transportation planning and engineering courses to determine which bicycle and pedestrian topics are commonly taught, and to identify gaps that should be addressed through this project. We organized the topics into eight broad categories that form the basis for the model curriculum. Using existing and new resources, we developed a curriculum module for each of the topic areas that included a PowerPoint with lecture notes, sample assignments and suggested readings. Several of the modules were used by the principal investigator (PI) in a course on bicycle and pedestrian transportation (USP 465-565) offered at Portland State University (PSU) in the fall 2011. In addition, we shared the identified reading list with the reference librarian for urban and public affairs at PSU's Millar Library to identify and prioritize resources that should be acquired. The librarian procured the top-priority items that will support student and faculty learning on bicycle and pedestrian transportation and provide reference materials for course offerings.

The PI wrote a proposal for a pilot faculty development course to provide training and resources to transportation engineering and planning faculty to help them integrate bicycle and pedestrian topics into their courses. The pilot was awarded funding from the Summit Foundation and the workshop was held in the summer of 2012.

This project advances the quality of education and, in turn, the practice of bicycle and pedestrian planning and design. It provides an up-to-date curriculum for teaching the topics that can be presented either as an entire class or as modules that faculty can use within other courses. The faculty development workshop will promote interest in teaching bicycle and pedestrian topics as part of transportation planning and engineering courses. Both the pilot course and curriculum will enhance the quality of courses and expand the amount of time devoted to these topics in courses across the country. This will raise the level of student interest and knowledge in bicycle and pedestrian planning and design, and better prepare them to work in the field and meet the growing demand for professionals with expertise in this field. 


\section{BACKGROUND AND OBJECTIVES}

\section{BACKGROUND}

Since the 1991 passage of the Intermodal Surface Transportation Efficiency Act (ISTEA), the amount of funding for and attention to bicycle and pedestrian infrastructure has increased significantly (Federal Highway Administration, 2009). During this time, there also has been increasing concern about global warming, carbon footprint, physical inactivity and rising obesity rates, and the economic costs of driving. These factors have led communities to focus more attention on developing safe and convenient infrastructure for cyclists and pedestrians, which in turn has raised expectations that transportation planners and engineers possess more skills and knowledge related to bicycle and pedestrian planning and design. However, there is a lack of relevant curriculum - and faculty interest and support - to teach these subjects at both the undergraduate and graduate levels.

\section{Course Curriculum}

Dill and Weigand (2010) reported on a national survey of university transportation planning and engineering faculty who teach transportation courses. Out of the 134 transportation courses that respondents provided information on, only three were specifically related to bicycle and pedestrian travel. Of the 134 courses, 59\% included topics related to bicycle and pedestrian issues, but most of the courses spend five hours or fewer on the topics.

In January 2010, more than 40 practitioners and faculty participated in a workshop at the annual meeting of the Transportation Research Board (TRB) focused on improving university education on bicycle and pedestrian topics. Participants in the workshop cited lack of appropriate curriculum as one of the barriers to increasing the amount of time devoted to these topics in course offerings.

The Federal Highway Administration (FHWA) developed a university course curriculum on bicycle and pedestrian transportation several years ago. However, Dill and Weigand (2010) found in their survey that only $28 \%$ of respondents used the FHWA materials and $46 \%$ had never reviewed them. Of those who used them, only $18 \%$ rated them very useful (five on a scale of one to five); $32 \%$ rated them useful (rated a four); and 23\% rated them not useful at all (rated a one). Participants in the TRB workshop stated that they did not find the FHWA course materials useful or adaptable to the learning objectives in their courses. Survey respondents also indicated that the materials that would be most helpful for including bicycle and pedestrian topics into courses were PowerPoint slides and lecture notes.

Courses that are specific to bicycle and pedestrian transportation are offered at the University of California at Berkeley, the University of North Carolina (UNC) and PSU, but none of these courses relies on the FHWA material for primary sources. The Pedestrian and Bicycle Information Center has posted the course that was taught at UNC during the previous academic year on its website, but it does not address all of the needs identified for a model curriculum. Clearly the findings of the survey and the TRB workshop, representing a national constituency, 
demonstrate a clear need for course materials on bicycle and pedestrian planning and design that are timely and relevant to the needs of today's students and practitioners.

\section{Faculty Development}

The Dill and Weigand survey also found a varying level of interest among faculty to include more bicycle and pedestrian topics in their courses. Less than half $(43 \%)$ indicated they were interested in including these topics, while about a quarter $(24 \%)$ indicated that they were not interested, showing a divergence on this topic. The TRB workshop participants, a self-selected group with a greater interest in including these topics in their courses, indicated that other faculty were less interested in teaching these subjects. However, the participants also indicated that lack of knowledge and resources on bicycle and pedestrian topics affect their interest level in teaching these subjects, and that they did not have the time to "get up to speed" on the subjects. These indications suggest that there is a need to both generate interest in these topics among faculty and support them by: increasing their knowledge and comfort level with the topic; offering materials they can use without spending time developing course lectures; identifying reading materials; and creating assignments. Creating both relevant curriculum and a faculty development course to increase knowledge on bicycle and pedestrian travel would provide a way to support faculty, generate interest in teaching these topics, and give them the resources they need to incorporate bicycle and pedestrian topics into existing courses.

\section{OBJECTIVES}

This project's primary objective was to fill identified needs for new curriculum and faculty support on bicycle and pedestrian education. Specifically, this project developed a module-based curriculum for bicycle and pedestrian planning and design that is current, relevant to practice, and is adaptable for use in a variety of course offerings by transportation planning and engineering faculty both in Oregon and across the country. In addition, we were able to update and build library resources available to support student learning and research on bicycle and pedestrian transportation by identifying and acquiring new materials. These materials are housed in PSU's Millar Library and are available through interlibrary loan to students and faculty at OTREC's partner institutions.

The project had secondary objectives:

$>$ To address faculty interest in teaching bicycle and pedestrian topics;

$>$ To enhance faculty knowledge on these subjects; and,

$>$ To provide resources for faculty members to integrate bicycle and pedestrian topics into existing courses by developing a proposal to fund a pilot faculty development workshop in Portland.

The long-term goal of this project was to improve the quality of education and, in turn, the practice of bicycle and pedestrian planning and design. It provides an up-to-date curriculum for teaching the topics, and promotes faculty interest in teaching bicycle and pedestrian topics as an element of transportation planning and engineering courses. This will raise the level of student interest and knowledge in bicycle and pedestrian planning and design, and better prepare them to work in the field and meet the growing demand for professionals with expertise in this field. 


\section{PROJECT DESCRIPTION}

\section{COURSE CURRICULUM}

The PI and graduate research assistant (GRA) reviewed existing course curricula and documents summarizing needs and deficiencies in bicycle and pedestrian curricula, and developed a priority list of topics to include in the model curriculum. We began with a scan of current courses in bicycle and pedestrian planning from universities across the country. In January 2011, we sent emails to the participants of the TRB's Curriculum Review Workshop that was held in January 2010. Instructors were asked to send sample syllabi, reading lists, and other material they may have used to develop curriculum for a course in bicycle and pedestrian transportation. They were also asked to provide contact information for others who may be teaching bicycle and pedestrian planning courses. In all, 43 professionals from across the United States were emailed. We obtained syllabi from 14 schools, listed below in Table 1, and reviewed them to inform the development of topics in the model curriculum.

\section{Table 1: Curriculum Scan Participants}

\begin{tabular}{|c|c|c|}
\hline University & Department & Course Title \\
\hline $\begin{array}{l}\text { FHWA \& PBIC University } \\
\text { Course }\end{array}$ & $\mathrm{N} / \mathrm{A}$ & Bicycle and Pedestrian Transportation \\
\hline $\begin{array}{l}\text { Georgia Institute of } \\
\text { Technology }\end{array}$ & City Planning & Urban Transportation \\
\hline Harvard University & School of Public Health & $\begin{array}{l}\text { Bicycle Environments in the U.S. and the } \\
\text { Netherlands/Denmark: Case studies in the } \\
\text { promotion of physical activity }\end{array}$ \\
\hline Portland State University & Urban and Regional Planning & Bicycle and Pedestrian Planning \\
\hline Texas A \& M & Civil Engineering & Transportation in City Planning \\
\hline UCLA & Department of Urban Planning & Pedestrian and Bicycle Planning Seminar \\
\hline University of Albany & School of Geography and Planning & $\begin{array}{l}\text { Bicycle, Walking and Trails: Innovations in } \\
\text { Transportation Planning }\end{array}$ \\
\hline $\begin{array}{l}\text { University of California } \\
\text { at Berkeley }\end{array}$ & $\begin{array}{l}\text { Department of City and Regional } \\
\text { Planning }\end{array}$ & Pedestrian and Bicycle Transportation \\
\hline $\begin{array}{l}\text { University of Illinois at } \\
\text { Chicago }\end{array}$ & Urban Planning and Policy & Introduction to Bicycle Planning \\
\hline University of North Carolina & Highway Safety Research Center & Bicycle and Pedestrian Transportation \\
\hline University of Oregon & $\begin{array}{l}\text { Planning, Public Policy and } \\
\text { Management }\end{array}$ & Bicycle Planning \\
\hline University of Washington & Urban Design and Planning & Pedestrian and Bicycle Planning \\
\hline W. Virginia Polytech Institute & Civil Engineering & Pedestrian and Bicycle Transportation \\
\hline University of Vermont & Global and Regional Studies & Bicycles, Globalization, Sustainability \\
\hline
\end{tabular}


Topics covered in each course were grouped by relevance to determine the topics that were most commonly taught and identify gaps in curriculum. These topics were then organized into eight broad categories which represent a holistic look at bicycle and pedestrian planning in university courses.

1. History and Relevance

2. Context of Other Movements

3. Master Planning

4. Pedestrian Facility Design

5. Bicycle Facility Design

6. Trail Design

7. Data Collection and Research

8. Education and Encouragement

Research for each of these module areas started by building off of the work of the other university courses and best practices research. Each module was developed to be a stand-alone unit that could be presented within a broader curriculum. The modules include the following elements:

1. Module overview

2. PowerPoint presentation (with notes for lecturer)

3. Handouts

4. Reading list for further information

5. Assignments for students (for in and out of class)

A secondary objective of the curriculum development project was to update and build library resources to support student learning and research on bicycle and pedestrian transportation. To begin, library staff created a preliminary listing of potential resources. The GRA reviewed this list of 332 resources to find those most relevant to the objective and not already owned by PSU or available on interlibrary loan. Additional resources were added through researching bicycle and pedestrian organizations' online libraries, reports and publications. Further research used searches on the WorldCat library and Amazon.com.

The final list of 137 relevant resources was then prioritized by subject area. The prioritized list was sent to four professionals for review for suggested additions before being given to the PSU library for purchase in April 2011. With a budget of $\$ 2,000$, the PSU library was able to purchase 33 books and manuals from the list, which are now part of the Millar Library collection. These books are now available to PSU students and instructors and through interlibrary loan to other schools in the region. The 33 purchased items are listed in Appendix A of this report and a spreadsheet with the full list of 137 resources is available on OTREC's website. 


\section{FACULTY DEVELOPMENT}

We reviewed existing documents, including the Dill and Weigand national scan and TRB workshop proceedings on bicycle and pedestrian curricula that describe barriers to teaching bicycle and pedestrian courses and identify teaching support requested by faculty. We wrote a proposal to the Summit Foundation to fund a pilot program to provide transportation engineering and planning faculty with the encouragement and resources to integrate more bicycle and pedestrian topics into their courses. Funding was awarded in fall 2011 to help offset travel and participation costs for faculty participants, and to provide honoraria to faculty leaders to prepare and facilitate sessions at the workshop, which was held in the summer of 2012. 


\section{OUTCOME AND RESULTS}

The curriculum developed through this project will advance the quality of education and, in turn, the practice of bicycle and pedestrian planning and design. It provides an-up-to date curriculum for teaching the topics that can be presented both as an entire class or modules that can be used by faculty as an element of other courses. By including these topics in courses offered by other disciplines such as transportation engineering, planning and community health, it has the potential to broaden the scope of students in these other disciplines who are exposed to the concepts of bicycle and pedestrian travel and foster interest in active transportation.

Both the pilot course and curriculum have the potential to enhance the quality of courses and expand the amount of time devoted to these topics in courses across the country. This will raise the level of student interest and knowledge in bicycle and pedestrian planning and design, and better prepare them to work in the field and meet the growing demand for professionals with expertise in this field.

The curriculum was distributed to participants in the faculty development workshop for use and feedback. In January 2012, the modules were presented at a follow-up workshop on university bicycle and pedestrian curriculum at the TRB annual meeting. The curriculum modules are available on the websites of the Initiative for Bicycle and Pedestrian Innovation (IBPI) as well as TRB's pedestrian and bicycle subcommittees.

IBPI hosted the faculty development workshop at PSU in July 2012. The workshop was designed to promote interest in teaching bicycle and pedestrian topics as part of transportation planning and engineering courses. IBPI publicized the workshop through regional and national organizations, including OTREC, TRB, the Pedestrian and Bicycle Information Center (PBIC) and other faculty networks. In the winter and spring of 2012, IBPI worked with engineering and planning faculty at PSU, Oregon State University and the University of Oregon to develop the workshop agenda, identify interest in leading workshop sessions, and review the model curriculum. Applicants described their interest in participating in the workshop; how they planned to use the information and materials; and, their commitment to participating in follow-up inquiries to provide feedback for future curriculum development and workshop offerings. 


\section{FUTURE ACTIVITIES}

Results will continue to be distributed through a combination of methods. In addition to the workshops and websites described above, ongoing outreach will target organizations, conferences and journals such as the Association of Collegiate Schools of Planning, the Institute of Transportation Engineers and the American Planning Association.

In addition, we will continue to follow up with workshop participants to obtain information on how they used the course materials and gather recommendations for revisions, both to the curriculum and the course. 


\section{REFERENCES}

Dill, J. and Weigand, L. "Incorporating Bicycle and Pedestrian Topics in University Transportation Courses: A National Scan" Transportation Research Board (2010).

Dill, J., Weigand, L., and Dixon, K. IBPI Bicycle and Pedestrian Education Program. Portland, OR: Oregon Transportation Research and Education Consortium. Report No. OTREC-ED080126 .

Federal Highway Administration. "Federal-Aid Highway Program Funding for Pedestrian and Bicycle Facilities and Programs."

http://www.fhwa.dot.gov/environment/bikeped/bipedfund.htm. (accessed March 16, 2010). 


\section{APPENDIX A: LIBRARY RESOURCES ACQUIRED}

1. Best-laid plans: how government planning harms your quality of life, your pocketbook, and your future, Randal O'Toole.

2. Bicycling \& the law: your rights as a cyclist, Bob Mionske.

3. Carfree design manual, J.H. Crawford foreword, Stavros Dimas.

4. Cities and cars: a handbook of best practices, edited by Roger L. Kemp.

5. City cycling, Richard Ballantine.

6. Environmentally conscious transportation, edited by Myer Kutz.

7. Gridlock: why we're stuck in traffic and what to do about it, Randal O'Toole.

8. Guide for the planning, design, and operation of pedestrian facilities.

9. Healthy cities: the intersection of urban planning, law and health, James A. Kushner.

10. Improving the pedestrian environment through innovative transportation design, prepared by Parsons Brinckerhoff.

11. Influences on bicycling propensity: a determination and measurement of the factors, John Parkin.

12. Infrastructure planning handbook: planning, engineering, and economics. Alvin S. Goodman, Makarand Hastak.

13. Joyride: pedaling toward a healthier planet, Mia Birk with Joe "Metal Cowboy" Kurmaskie.

14. Measuring bicycle compatibility in the urban environment: a study of Calgary, Timothy Blair.

15. My kind of transit: rethinking public transportation in America, Darrin Nordahl.

16. One less car: bicycling and the politics of automobility, Zack Furness.

17. Parking management best practices, Todd Litman.

18. Pedal power: the quiet rise of the bicycle in American public life, J. Harry Wray.

19. Pedestrian behavior [electronic resource]: models, data collection and applications, edited by Harry Timmermans.

20. Regenerating older suburbs, edited by Richard B. Peiser and Adrienne Schmitz.

21. Reinventing the automobile: personal urban mobility for the 21 st century, William J. Mitchell, Christopher E. Borroni-Bird, and Lawrence D. Burns.

22. Retooling for growth: building a 21st century economy in America's older industrial areas, Richard M. McGahey, Jennifer S. Vey, editors.

23. Road more traveled: why the congestion crisis matters more than you think, and what we can do about it, Ted Balaker and Sam Staley.

24. Sustainable automobile transport: shaping climate change policy, Lisa Ryan, Hal Turton.

25. Traffic: why we drive the way we do (and what it says about us), Tom Vanderbilt.

26. Transport and neighbourhoods, Hank Dittmar.

27. Transportation in a climate-constrained world, Andreas Schaefer ... [et al.].

28. U.S. traffic calming manual, Reid Ewing and Steven J. Brown.

29. Urban structure matters: residential location, car dependence and travel behavior, Petter Nass.

30. Walk for your life! restoring neighborhood walkways to enhance community life, improve street safety and reduce obesity, Marie Demers.

31. Walkability of neighborhoods: a critical analysis of the role played by zoning codes in creating a walkable environment.

32. Walkable city: from Haussmann's boulevards to Jane Jacobs' streets and beyond, Mary Soderstrom.

33. Pedaling revolution : how cyclists are changing American cities, by Jeff Mapes 



\section{GOTREC \\ AND EDUCATION CONSORTIUM}

P.O. Box 751

Portland, OR 97207

OTREC is dedicated to stimulating and conducting collaborative multi-disciplinary research on multi-modal surface transportation issues, educating a diverse array of current practitioners and future leaders in the transportation field, and encouraging implementation of relevant research results. 